\title{
The Evaluation of Mode Shift Preference within Bus Rapid Transit-oriented Development Context
}

\author{
Lutfi Prayogi $^{1}$, Finta Lissimia ${ }^{1}$ \\ ${ }^{I}$ Department of Architecture, Faculty of Engineering, Universitas Muhammadiyah Jakarta, Indonesia \\ lutfi.prayogi@umj.ac.id
}

\begin{abstract}
Bus rapid transit (BRT) has been acknowledged as a mode of transit that is appropriate to be constructed in conjunction with transit-oriented development (TOD). In order to evaluate the occurrence of a TOD with BRT systems as its component, evaluating the passengers' mode shift triggered by the provision of the BRT systems is one approach that can be taken. Within the mentioned type of TOD, the built environment should support, or even more trigger, the passengers' mode shift into taking the BRT systems. This article evaluates the mode shift preference of Transjakarta BRT passengers. This article also evaluates the heterogeneity of mode shift preference among various groups of Transjakarta passengers. This article qualitatively describes the mode shift preference, while the data was collected, processed, and presented in quantitative manners. Information regarding the mode shift preference is collected through an indirect interview. The statistics of the mode shift preference is processed using simple statistical analysis and Bartlett's test for variance heterogeneity. It is found that the role of the built environment in supporting Transjakarta passengers' mode shift into taking Transjakarta is relatively low. It is also found that the variance of the mode shift preference is homogeneous across various groups of Transjakarta passengers. This article concludes that the envisioned bus rapid transitoriented development (BRTOD) hasn't been fully occurring in areas around Transjakarta corridors.
\end{abstract}

(C) 2021 IJBESR. All rights reserved.

Keywords: Mode shift, bus rapid transit, transit-oriented development, Transjakarta

\section{Introduction}

Bus rapid transit-oriented development (BRTOD) is a type of TOD that has been discussed by a number of researchers lately. A number of researchers have recorded and discussed the development of high-density multi-function built environment along BRT corridors in a number of cities [1-4]. A discussion that is worth to note is the one presented by Lindau, et al. [3]; he noted that the built environment around BRT corridors in Curitiba, Brazil, has been developing into a high-density and multi-function one as planned when the BRT corridors being conceived. Cervero and Dal [5] provided an overview of BRTOD cases worldwide.
In line with the discussion of BRTOD, a number of researchers have tried describing the influence of the provision of BRT systems towards the built environment around the systems. Stokenberga [6] provided a comprehensive overview of such researches. Prayogi and Sari [7] summarized some approaches used in evaluating the influence of BRT systems towards the built environment around the systems. The two commonly used approaches are evaluating the influence of the BRT systems on property value around the systems and evaluating the influence of the BRT systems on transit ridership. Prayogi [8] argued that one other valid but still rarely utilized approach is by evaluating the mode shift towards taking the BRT systems triggered by the provision of the systems. He argued that 
this approach is in line with the commonly agreed TOD principles and goals, thus it is in line with the discussion of BRTOD. Furthermore, he also noted that within a BRTOD, the built environment should support the mode shift.

Prayogi and Hantono [9] and Prayogi and Satwikasari [10] provided a summary of issues that are potentially considered by BRT passengers prior to deciding to mode shift to taking the bus rapid transit (BRT) system. The issues consist of ones related to the BRT system's service, including the systems's reliability (i.e., vehicle speed, frequency, and headway), fare competitiveness and affordability, network integration, and general comfort and safety. The issues also consist of ones related to the built environment around the BRT system, including the street network design around the BRT stops, availability of access to certain places to and from the BRT stops, and walkability and cycle ability of streets around the BRT stops. Prayogi and Hantono [9] argued that BRT passengers perceive the distance they travel to and from the BRT stops. BRT passengers also perceive the safety and comfort on routes they travel to and from the BRT stops. Prayogi and Hantono [9] argued that these perceptions are potentially considered by BRT passengers prior to deciding to mode shift to taking the BRT system. Prayogi and Hantono [9] highlighted the importance of exploring the mentioned perceptions when trying to understand the BRT passengers' mode shift preference.

Furthermore, Prayogi and Satwikasari [10] noted that the BRT passengers' mode shift preference may not be homogeneous among various groups of passengers. The mode shift preference may vary among passengers of different background, including different income, ownership of personal vehicle and related driving license, and age. The mode shift preference may also vary among passengers of different types of trips, including different trip purpose, trip time, and trip distance. They argued that the general mode shift preference may not be uniformed with the mode shift preference of each group of passengers. They suggested to check the heterogeneity of the BRT passengers' mode shift preference in order not to make an overgeneralizing conclusion regarding the mode shift preference

This article tests evaluating the Transjakarta BRT system passengers' mode shift preference within BRTOD context. This article looks into the factors triggering Transjakarta passengers to mode-shift to taking Transjakarta. This article also looks into the role of the built environment in supporting, or even more triggering, the mentioned mode shift. Besides trying to explore the potential BRTOD case involving Transjakarta, this article also intends to test carrying out the previously mentioned valid but still rarely utilized approach in evaluating the influence of BRT systems towards the built environment. This article intends to test evaluating the mode shift towards taking the BRT systems triggered by the provision of the systems.

\section{Material and Methods}

This articles tests evaluating the Transjakarta passengers' mode shift preference, as well as checking the heterogeneity of the mode shift preference among various groups of Transjakarta passengers. The research questions are "What are the factors making Transjakarta passengers mode shift to taking Transjakarta?" and "Are the variance of the factors homogeneous across all identified groups of passengers?" This article was written through a qualitative and descriptive approach using inductive rationalization. The theories regarding factors potentially triggering mode shift and mode shift potential variance heterogeneity mentioned in the previous section was used to describe the Transjakarta passengers' mode shift preference. 
However, the mode shift preference data was collected and processed using quantitative techniques. The data was collected using indirect interview in the form of online questionnaire filling. The questionnaire contains mostly closed questions with answer choices taking form of Likert scale of 1 to 6,1 stands for the most negative answer and 6 stands for the most positive answer. Following the suggestion of Prayogi and Hantono [9], the questionnaire asks passengers' perception on Transjakarta's service and the built environment around Transjakarta corridors. The questionnaire also asks the passengers' background and the type of trip the passengers do. As of July 2019, the questionnaire was filled by 332 verified respondents. The number of the respondents is approximately $0,3 / 1000$ of Transjakarta daily passengers of the time. Besides been processed using simple statistical analysis, the statistics of the mode shift preference was also processed using Bartlett's test in order to check its variance heterogeneity. [11]

\section{Results and Discussions}

Out of 332 respondents, $316(95 \%)$ answered that there is another way of travelling they do before mode shifting to taking Transjakarta for the same kind of trip. 121 (36\%) answered that they shifted from using personal motorized vehicle (car and or motorcycle), while 67 (20\%) answered that they shifted from using car and or motor taxi (ojek motor). The other 39\% of the respondents answered that they shifted from walking, cycling, or using other mode of public transit services. Figure 1 shows the proportion of mode shift occurring among the interviewed Transjakarta passengers.
Is there any other mode of transport you use prior to shifting to taking Transjakarta?

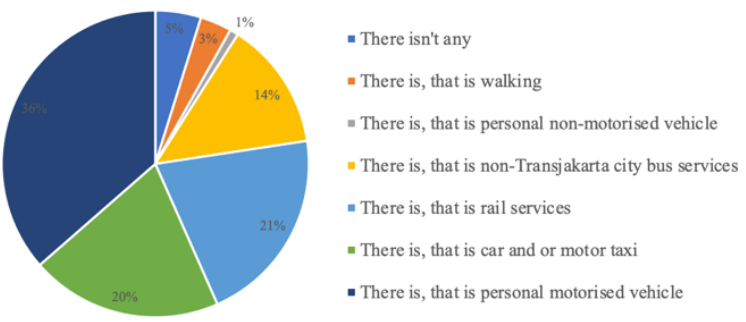

Source: (Authors' analysis, 2020)

Figure 1: Proportion of mode shift occurring among the interviewed Transjakarta passengers

The passengers who stated that they mode shifted from other way of travelling stated their factors for doing so. Transjakarta's fare is the most mentioned factor, while Transjakarta's reliability (buses' speed and frequency) is the least mentioned factor. Transjakarta's easiness to reach and use is the second least mentioned factor. Figure 2 shows the distribution of factors for mode shifting to using Transjakarta from the interviewed Transjakarta passengers.

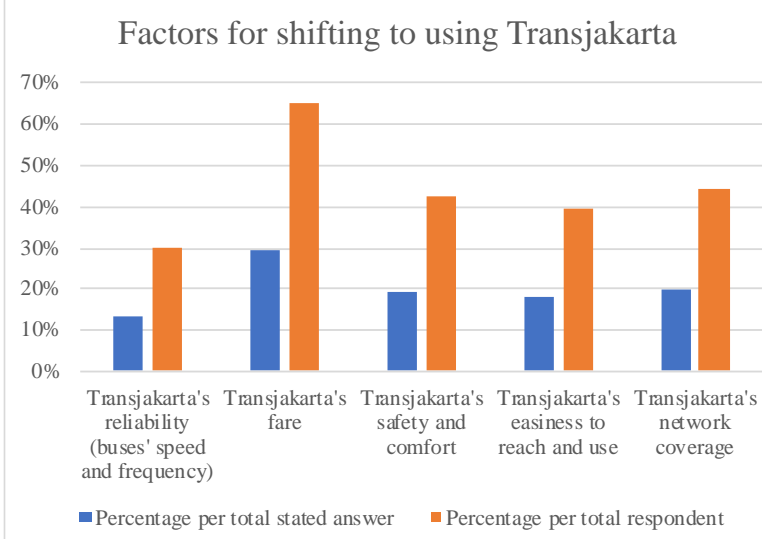

Source: (Authors' analysis, 2020)

Figure 2: Distribution of factors for mode shifting to using Transjakarta from the interviewed Transjakarta passengers

The passengers who stated that they mode shifted from other way of travelling also gave their detailed opinion regarding various factors that potentially trigger their mode shift as have been discussed in section 2.1. They gave their opinion regarding the speed, fare affordability, safety, comfort, easiness to reach, easiness to use, and network width of Transjakarta 
compared to the other way of travelling they shift from. Within a Likert scale of 1 to 6,1 stands for the most negative answer and 6 stands for the most positive answer, the factor that got the highest mean score is fare affordability and network width. The factor that got the lowest mean score is speed. Table 1 shows the scores of each factor.

Table 1: Scores of factors triggering mode shift among the interviewed Transjakarta passengers

\begin{tabular}{|c|c|c|c|c|c|c|c}
\hline & Faster & $\begin{array}{c}\text { More } \\
\text { affordable }\end{array}$ & Safer & $\begin{array}{c}\text { More } \\
\text { comfortable }\end{array}$ & $\begin{array}{c}\text { Easier } \\
\text { to reach }\end{array}$ & $\begin{array}{c}\text { Easier } \\
\text { to use }\end{array}$ & $\begin{array}{c}\text { Have } \\
\text { wider } \\
\text { network }\end{array}$ \\
\hline Mean & 3,47 & 4,79 & 4,75 & 4,63 & 4,18 & 4,42 & 4,79 \\
\hline $\begin{array}{c}\text { Deviation } \\
\text { standard }\end{array}$ & 1,81 & 1,24 & 1,03 & 1,21 & 1,32 & 1,18 & 1,26 \\
\hline
\end{tabular}

Source: (Authors' analysis, 2020)

The respondents gave their opinion regarding the quality of components of the built environment around the Transjakarta corridors. The components include the sidewalk, on-street crossing, and elevated crossing. Within table 1, their quantified opinions are synthesized into the 'Easier to reach' factor. The 'Easier to reach' factor only scores 4,18 , that is the second lowest among the seven factors. We may conclude from this that generally the interviewed passengers don't think the built environment around the Transjakarta corridors trigger their mode shift as strong as other factors do. We may conclude that the built environment around Transjakarta corridors hasn't really trigger the residents to mode shift to taking Transjakarta.

The variance of the scores of factors triggering mode shift shown in table 1 is relatively homogeneous across various groups of Transjakarta passengers. The variance is relatively homogeneous among interviewed Transjakarta passengers of different gender, age, monthly income, and vehicle ownership. The variance is also relatively homogeneous among interviewed Transjakarta passengers doing trips of different time, distance, and duration. Table 2 shows the outputs and used constant of the Bartlett's test and the conclusion from the test.

Table 2: Outputs and used constant of the Bartlett's test for variance difference and the conclusion from the test

\begin{tabular}{|c|c|c|c|c|}
\hline Groups & $\begin{array}{c}\text { Bartlett's } \\
\text { test statistic }\end{array}$ & $\begin{array}{c}\text { Probability } \\
\text { constant }\end{array}$ & \begin{tabular}{|c}
$\begin{array}{c}\text { Critical } \\
\text { value of chi } \\
\text { square }\end{array}$ \\
\end{tabular} & Conclusion \\
\hline \multicolumn{5}{|c|}{ Based on passengers' background } \\
\hline Gender & 0,01 & \multirow{4}{*}{0,05} & 3,84 & No significant difference \\
\hline Age & 1,29 & & 5,99 & No significant difference \\
\hline $\begin{array}{c}\text { Monthly } \\
\text { income }\end{array}$ & 1,33 & & 9,49 & No significant difference \\
\hline $\begin{array}{c}\text { Vehicle } \\
\text { ownership }\end{array}$ & 0,12 & & 3,84 & No significant difference \\
\hline \multicolumn{5}{|c|}{ Based on types of trip } \\
\hline $\begin{array}{c}\text { Trip } \\
\text { purpose }\end{array}$ & 9,06 & \multirow{4}{*}{0,05} & 5,99 & There is a significant difference \\
\hline Trip time & 0,47 & & 5,99 & No significant difference \\
\hline $\begin{array}{c}\text { Trip } \\
\text { distance }\end{array}$ & $-15,49$ & & 14,07 & No significant difference \\
\hline $\begin{array}{c}\text { Trip } \\
\text { duration }\end{array}$ & $-1,75$ & & 12,59 & No significant difference \\
\hline
\end{tabular}

Source: (Authors' analysis, 2020)

As shown in table 2, the variance of the scores of factors triggering mode shift is heterogeneous among Transjakarta passengers doing trips of different purposes. It is different among Transjakarta passengers doing trips for commuting, leisure, and doing daily errands. Among those different groups, the 'Faster' factor doesn't consistently rank as the lowest scoring factor, while the 'Have wider network' doesn't consistently rank as the highest scoring factor. 
Table 3: Summary of scores of factors triggering mode shift among the interviewed Transjakarta passengers doing trips of different purposes

\begin{tabular}{|c|c|c|c|c|c|c|c|}
\hline & Faster & $\begin{array}{c}\text { More } \\
\text { affordable }\end{array}$ & Safer & $\begin{array}{c}\text { More } \\
\text { comfortable }\end{array}$ & $\begin{array}{c}\text { Easier } \\
\text { to reach }\end{array}$ & $\begin{array}{c}\text { Easier } \\
\text { to use }\end{array}$ & $\begin{array}{c}\text { Have } \\
\text { wider } \\
\text { network }\end{array}$ \\
\hline \multicolumn{7}{|c|}{ Trips for commuting } \\
\hline Mean & 3,36 & 4,93 & 4,72 & 4,53 & 4,08 & 4,37 & 4,73 \\
\hline Dev. standard & 1,77 & 1,20 & 1,06 & 0,93 & 1,25 & 1,14 & 1,29 \\
\hline \multicolumn{7}{|c|}{ Trips for leisure } \\
\hline Mean & 3,64 & 4,55 & 4,79 & 4,78 & 4,38 & 4,46 & 4,92 \\
\hline Dev. standard & 1,87 & 1,31 & 0,98 & 0,89 & 1,42 & 1,28 & 1,18 \\
\hline \multicolumn{7}{|c|}{ Trips for doing daily errands } \\
\hline Mean & 3,50 & 6,00 & 3,00 & 4,00 & 2,00 & 4,00 & 2,00 \\
\hline Dev. standard & 1,80 & 0,49 & 1,02 & 1,36 & 1,02 & 0,75 & 1,33 \\
\hline
\end{tabular}

Source: (Authors' analysis, 2020)

\section{Conclusion}

We may conclude from the previous section that there are a number of factors triggering Transjakarta passengers to mode shift to taking Transjakarta. The factors are Transjakarta's reliability, fare, safety and comfort, easinees to reach and use, and network coverage. The factors are not equal; some factors affect more passengers while some other factors affect less passengers. Transjakarta's fare affects the most (65\%) from the interviewed passengers while while Transjakarta's reliability affects the least (30\%) from the interviewed passengers. Similarly, the interviewed passengers perceive that Transjakarta's fare is significantly cheaper $(4,79$ within the scale of 1 to 6$)$ than their previous way of travelling and perceive that their travel duration by using Transjakarta is just slightly faster $(3,47$ within the scale of 1 to $6)$ than their previous way of travelling. The statistics of the quantified perception is relatively homogeneous across all groups of Transjakarta passengers except across pasenggers doing trips of different purpose.

Within bus rapid transit-oriented development (BRTOD) context, it is necessary to highlight the findings regarding how the built environment around Transjakarta corridors trigger mode shift to taking Transjakarta among Transjakarta passengers. It is found that Transjakarta's easiness to reach and use affects the second least $(40 \%)$ from the interviewed passengers. The interviewed passengers also perceive that Transjakarta is rather easier $(4,18$ within the scale of 1 to 6$)$ to reach than their previous way of travelling. Within the envisioned BRTOD, the built environment around the BRT corridors should trigger the residents to mode shift to taking the BRT systems. [8] The easier to reach factor is arguably should score higher than other factors that trigger the residents to mode shift to taking the BRT systems.

Considering that Transjakarta has an extensive network (13 corridors and more than 100 routes prior as of July 2019) and various services (BRT, non-BRT, and feeder services), it is arguably necessary to investigate deeper into specific corridors and or services. It is safe to assume that the mode shift preference of passengers of Transjakarta route 1 (a BRT service) along Sudirman-Thamrin route is different from the mode shift preference of passengers of Transjakarta route $2 \mathrm{~K}$ (a feeder service) in Jakarta Garden City.

Considering the works reviewed by Prayogi and Hantono [9], it is also important to thoroughly analyse the built environment around the Transjakarta corridors and relate it with the passengers perception of the built environment and how the built environment trigger them to shift to taking Transjakarta. Findings from such research would be beneficial for the creation of a design standard of the built environment that triggers its residents to shift to taking transit.

\section{Acknowledgement}

This research was funded by Pusat Afiliasi dan Riset Teknologi (Pakarti) Fakultas Teknik Universitas Muhammadiyah Jakarta (FT UMJ) in 2018 and by Lembaga Penelitian dan Pengabdian Masyarakat (LPPM) Universitas Muhammadiyah Jakarta in 2020. 


\section{References}

[1] Cervero R. The transit metropolis: A global inquiry. Washington, United States: Island Press; 1998

[2] Kamruzzaman M, Baker D, Washington S, Turrell G Advanced transit oriented development typology: Case study in Brisbane, Australia. J. of Trans. Geo. 2014;34:54-70

[3] Lindau LA, Hidalgo D, Facchini D. Bus Rapid Transit in Curitiba, Brazil: A Look at the Outcome After 35 Years of Bus-Oriented Development. Transp. Res. Rec.: J. of the Transp. Res. Board. 2010;2193(10)

[4] Suzuki H, Cervero R, Iuchi K. Transforming cities with transit: Transit and land-use integration for sustainable urban development. Washington, United States: World Bank Group; 2013

[5] Cervero R, Dai D. BRT TOD: Leveraging transit oriented development with bus rapid transit investments. Transp. Pol. 2014;36:127-138

[6] Stokenberga A. Does bus rapid transit influence urban land development and property values: A review of the literature. Transp. Rev. 2014

[7] Prayogi L, Sar Y. The Approaches on Assessing the Influence of a Bus Rapid Transit Sytem on

Urban Development. Int. J. of Built Env. and Sci. Res. 2019;3(2):105-110

[8] Prayogi L. Bus Rapid Transit Oriented Development: A Review of Modal Shift-triggering Ability of a Bus Rapid Transit (BRT) System. Proc. of Int. Works. on Urb. Plan. and Com. Dev. 2017;75-84

[9] Prayogi L, Hantono D. Bus Rapid Transit-oriented Development: A Review of Built Environment Qualities Potentially Triggering Bus Rapid Transit Passengers' Modal Shift. Int. J. of Eng. Res. and Tech. 2018;7(8):302305

[10] Prayogi L, Satwikasari AF. Bus Rapid Transitoriented Development: An Identification of Bus Rapid Transit System Passengers' Modal Shift Potential Considerations. CSID J. of Inf. Dev. 2019;2(1):127-136

[11] Arsham H, Lovric M. Bartlett's Test. In International Ecyclopedia of Statistical Science. Berlin, Germany: Springer; 2011 